\title{
TIEDETTÄ ON PUOLUSTETTAVA!
}

\begin{abstract}
Ranskalainen Joe Metzger aloittaa kirjansa Für die Wissenschaft (ilmestynyt sarjassa Zur Kritik der bürgerlichen Ideologie, no 68 Berliini 1976) paradoksilla: "Vuonna 1974 on Ranskassa puolustettava tiedettä. Descartesin ja ensyklopedistien maassa leviävät obskurantismi ja maailmanloppuideologiat laajemmin kuin koskaan aikaisemmin, niitä jopa suositaan ja kehitellään kaikkein korkeimmissa piireissä."
\end{abstract}

Metzgerin teemana on tieteen puolustaminen. Hän aloittaa kiistakirjoituksensa voimakkaasti: Ranskan kapitalistisen yhteiskunnan ja sen ideologian kriisin seuralaisena on tieteen kriisi; tieteen, joka muodostaa "nykyisin erään ideologisen taistelun tärkeimmistä rintamista". Vastaiskun on Metzgerin mukaan oltava offensiivista, sen on perustuttava laajempaan ja syvällisempään käsitykseen tieteestä ja tutkijoiden tehtävistä, kuin väitteet, joilla tiedettä vastaan hyökätään.

Metzgerin teema herättää kysymyksen: Onko tilanne Ranskassa rinnastettavissa suomalaisiin olosuhteisiin? Asetelma yleispiirteiltään on samankaltainen. Suomen tieteen perinteestä ei löydy Descartesia, mutta siihen sisältyy oman kansallisen kehityksemme kannalta olennaisen arvokas edistyksellinen linja. Ja hyökkäyksiä niin tutkimuksen tekijöitä kuin tutkimuksen teon edellytyksiäkin vastaan on viime vuosina riittänyt. Mutta ovatko yleisen asetelman konkreettiset ainekset samoja?

Joe Metzger käy kirjoituksessaan läpi laajan aihepiirin: Hän käsittelee tieteen yhteiskunnallista roolia, tieteen ja filosofian keskinäissuhdetta, tieteellis-teknistä kumousta, sosialismia ja tiedettä sekä tutkimuksen vaatimia välittömiä yhteiskunnallisia reformeja. Käsittely ei ehkä ole kaikin osin kovin syvällistä, mutta nostaa esiin - kuten kiistakirjoituksen tulee - joukon olennaisia kysymyksiä.

Metzgerin hallitsevan teeman muodostaa tieteen ja yhteiskunnan suhde. Hän pyrkii arvioimaan tieteellisen edistyksen käsitettä sekä siihen vaikuttavia tekijöitä, ja tällöin on kyse nimenomaan tieteellisen edistyksen yhteiskunnallisista edellytyksistä. Metzger tekee erottelun tieteen $s$ is äisen k r i i s i n (tai "tiedon kriisin" Krise des Wissens) ja tutki$m u k s$ e $n k r$ i i s i n välillä. Näistä edellinen on teoreettista kehitystä eteenpäin vievä, kunkin tieteenalan sisäisenä ilmenevä ristiriita kertyneen tiedon ja vallitsevan teorian välillä; uuden teorian kehittäminen on tämän kriisin ratkaisu, joka samalla muodostaa laadullisen edistysaskeleen tieteen kehityksessä. Klassisia esimerkkejä tästä ovat evoluutioteoria biologiassa, tilanne fysiikassa 1800 / 1900-lukujen vaihteessa tai vaikkapa aikanaan Newtonin taivaanmekaniikka.

Tutkimuksen kriisi sen sijaan on yhteiskunnallisen kriisin eräs välitön osa. Siinä on kyse nimenomaisesti tieteellisen edistyksen perusedellytyksistä, mahdollisuuksista tehdä tieteellistä työtä.

Näiden kahden käsitteen välille ei voi rakentaa muuria, minkä Metzger itsekin toteaa. Tutkimuksen kriisi varmasti vaikeuttaa eri tieteenalojen sisäisten teoreettisten ongelmien ratkaisemista. Vielä olennaisempaa on tieteen tulosten kasvava ideologinen merkitys, joka tekee niistä myös sisällöllisèsti, teoreettisesti aatteellisen taistelun kohteita. Olivathan toki evoluutioteorian läpimurto 1800 -luvulla tai fysiikan tulokset vuosisadan alus- sa materialistisen ja idealistisen maailmankatsomuksen kiivaan yhteenoton kohteita. Yhteiskuntatieteiden asema on ideologisessa taistelussa vielä välittömämpi, on oma ongelmansa, voidaanko niissä lainkaan erottaa tieteen sisäistä kriisiä yhteiskunnallisista yhteyksistään. Käsitteiden erottelu on kuitenkin käsittääkseni hyödyllinen erityiscsti siksi, että käsite "tutkimuksen kriisi" kokoaa joukon nykyiselle tilanteelle tyypillisiä ilmiöitä. Metzger esittää joukon esimerkkejä, jotka osoittavat tieteen aseman heikkenemisen Ranskassa:

Tutkimuksen rahoituksen osuus bruttokansantuotteesta oli vuonna $19672,28 \%$, mutta vuonna 1973 enää $1,53 \%$; vuonna 1974 määrärahojen reaaliarvo laski. Korkeakouluopiskelijoiden määrää $\mathrm{mm}$. luonnontieteellisissä aineissa ja lääketieteessä rajoitetaan. Korkeakouluista valmistuneiden keskuudessa vallitsee työttömyyttä, ja valmistuneet joutuvat joukoittain hakeutumaan koulutustaan vastaamattomiin tehtäviin; samanaikaisesti on kuitenkin puutetta tutkijoista ja korkeasti koulutetuista tieteellis-teknisistä kaadereista. Tutkimuslaboratorioiden määrärahoja kiristetään ja niitä pakotetaan rahoittamaan toimintaansa tuotto- ja jopa voittoperiaatteella. Joitakin tieteenaloja väitetään "ylellisyydeksi" ja syrjitään täysin - mm. arkeologian, kartografian ja biologian joidenkin alojen tutkimus on kokonaan näivettymässä. Kansallinen tutkimus vaarantuu USA:n paineen vuoksi etenkin teknologisen kehityksen avainaloilla kuten tietokone- ja lentokonetekniikassa.

Näiden ilmiöiden taustaksi Metzger nostaa ranskalaisen kapitalismin kehityksen 1960-70luvuilla. Kärjistynyt taloudellinen kriisi on johtanut "malthusilai- 
seen" supistuspolitiikkaan lukuisilla julkisen kulutuksen sektoreilla $\mathrm{mm}$. tutkimusmäärärahojen jaossa. Valtiovallan korkeimmat edustajat, mm. pääministeri, on esittänyt että tutkimusmäärärahojen lisääminen on mahdollista vasta kun "taloudellinen tilanne on parantunut".

Metzgerin esittämät seikat tuovat hämmästyttävän välittömästi mieleen tilanteen Suomessa. Erityisesti tutkimusmäärärahojen supistukset ja korkeakoulujen heikkenevät taloudelliset resurssit ovat yhteisiä piirteitä. Suomesta tunnemme vielä muita piirteitä, jotka täydentävät kuvaa: Ennen kaikkea tällainen on taloudellisen kuristamisen seuralaisena ilmenevä hallinnollinen mielivalta ja poliittinen syrjintä, joita on ilmennyt $\mathrm{mm}$. kun on sovellettu käytäntöön valtionhallintoa koskevia supistuspäätöksiä Suomen Akatemiassa ja eri hallinnonhaarojen tutkimusyksiköissä. Resurssien niukkuus on veruke, jonka nojalla hallinnollinen kontrolli kaikkeen tutkimukseen nähden tiukkenee ja samalla eräs tieteellisen työn perusedellytyksistä, mahdollisuus luovaan, kriittiseen, pitkäjänteiseen työskentelyyn romuttuu.

Jürgen Kucz y n s ki esittää kirjassaan Wissenschaft Heute und Morgen (Berliini 1973) tieteellisen edistyksen erääksi perusedellytykseksi nykyaikana tieteen "intensivoinnin". Hän ottaa taustaksi tunnetut luvut, jotka kuvaavat tieteen ekspansiota määrärahojen, tutkijamäärän, julkaisumäärän jne. suhteen viime vuosikymmeninä ja -satoina; nämä osoittavat, että tieteen yhtä nopea kehitys laajenevaan suuntaan on tulevaisuudessa mahdotonta.

Kuczynski esittää "intensivoinnin" turvaamiseksi ajatuksia, jotka ovat erityisen mielenkiintoisia kahdelta osin: Ensinnäkin hän ko- rostaa strategista suunnittelua eli tieteen suunnittelua, joka perustuu laajaan kokonaisnäkemykseen tieteellisen työn sisällöstä ja edellytyksistä sekä yleensä että kullakin tieteenalalla erikseen, ja toimenpiteistä, joilla turvataan mahdollisimman suotuisat edellytykset tutkimustyölle. Toiseksi hän korostaa tieteellisen luovuuden merkitystä. Tämän tuo kirkkaimmin esiin teoksessa siteerattu neuvostoliittolaisen akateemikon, ydinfyysikko P. L. Kapitsan toteamus: "Tieteessä on luova elementti kaikkein arvokkain. Suunnitelmat ja määrärahat on siksi suunnattava niin, että ne edistävät tieteellisen luomisen vapautta."

Kuczynskin ajatukset tieteen "intensivoinnista" tekee mielenkiintoiseksi se, että esitetyt toimenpiteet ovat erityisen räikeässä ristiriidassa niin Ranskassa kuin Suomessakin ilmenevän nykykehityksen kanssa. Kotimaasta tuntemamme ilmiöt: tutkijoiden jatkuva apurahahakemuskierre, julkaisumäärärahojen supistuminen, korkeakoulututkijoiden opetus- ja hallintotehtävien lisääntyminen, tutkimuksen kontrollin tiivistyminen ja vaikkapa suunnitelmat heittää tieteelliset seurat ulos nykyisestä Tieteellisten seurain talosta saavat näin uuden ulottuvuuden. Kyse ei ole pelkästään tutkimusedellytysten huononemisesta tässä ja nyt. Kyse on todella vakavasta tieteellisen edistyksen tulevien edellytysten näivertämisestä.

Tämä asetelma nostaa esiin usein keskustelussa olleen ongelman: tieteen autonomian. Metzger toteaa kirjoituksessaan, että tieteelle on kehittynyt suhteellinen autonomia, osin jo siksi, että tieteen suhteet yhteiskuntaan ja ta- louteen ovat hyvin monimutkaiset.

Tieteen autonomiasta on keskustelussa ollut esillä kaksi sitä puoltavaa, mutta silti toisilleen vastakkaista käsitystä. $\mathbf{M m}$. tätä käsittelee Jürgen Kuczynski kirjassaan Die vertauschte Eule der Minerva (Berliini 1974), jossa hän käy läpi englantilaisen vuodesta 1962 lähtien ilmestyneen "M in e rva" -lehden ensimmäisen kymmenvuotiskauden sisältöä.

Minerva -lehdessä ilmestyneissä artikkeleissa on ollut tyypillistä tieteen autonomian korostus, mutta sen asettaminen yhteiskunnallisen edistyksen vastakohdaksi. Esimerkiksi lehden avustajiin lukeutuva tunnettu fyysikko Michael Polanyi on todennut: "Jokainen yritys antaa tieteelliselle tutkimukselle muita kuin sille ominaisia tavoitteita merkitsee yritystä irroittaa tutkimustyö tieteen edistämisestä." Tästä on vain askel siihen, että julistetaan yhteiskunnalliset olosuhteet tieteen kehityksen ja tutkijoiden työn kannalta täysin merkityksettömäksi. Näin esimerkiksi Sir Eric Ashby, englantilaisen tiedepoliittisen keskustelun johtava nimi, on lehdessä absolutisoinut "akateemisen vapauden" ja mm. eräässä selvityksessään eteläisen Afrikan yliopisto-olosuhteista esittänyt, että Etelä-Afrikan Tasavallassa vallitsee tieteelliselle työlle kerrassaan ihanteelliset olosuhteet!

Kuten Kuczynski itse toteaa, tieteen autonomian ja akateemisen vapauden korostamisessa on järkevä ydin. Sen muodostaa tieteellisyys - tieteen sisällöllisiä kysymyksiä on arvioitava tieteen omin kriteerein, ja tämä nimenomaan edellyttää tieteellisen yhteisön ja tieteellisen kritiikin vapautta.

Todellisuus tieteellisen autonomian kohdalla on kuitenkin Länsi-Euroopan maissa Minervan kir- 
joittelulle vastakkainen: Tosiasiassa tieteen autonomia kaventuu, mikäli sitä enää yleensä on jäljellä - tähän johtaa niin tutkimuksen välitön alistaminen suuryritysten voittopyrkimyksille kuin tutkimuksen hallinnollisen kontrollin tiukkeneminenkin - ja autonomian romuttamisesta vastaavat ne, jotka kaikkein äänekkäimmin puhuvat autonomian puolesta. Sillä kun "akateeminen vapaus" yritetään irroittaa yhteiskunnallisesta edistyksestä, se tosiasiassa sidotaan yhteiskunnalliseen taantumukseen.

Kotimaasta löydämme tästä havainnollisena esimerkkinä $\mathrm{K}$ a $\mathbf{n}$ a$v$ a-lehden vakinaisen avustajan Seikko Eskolan, joka on manannut erityisen voimakkaita madonlukuja suomalaiselle edistykselliselle tutkimukselle ja tukenut sitä vastaan kohdistettuja ulkotieteellisiä hyökkäyksiä. Kuitenkin samainen Eskola kirjoitti Kanava -lehlessä no 5/73 (nimimerkillä S.E.) otsikkonaan Tiedebyrokraattien kaappaussuunnitelma seuraavasti: "Tutkijan turva on vain vallan hajauttamisessa ja tutkimustyön tekijäin mahdollisuudessa itse vaikuttaa työtään koskeviin päätöksiin. Mutta hallituksen suunnitelmat kulkevat päinvastaiseen suuntaan."

Tämä näennäinen ristiriita tieteen autonomian ja tieteen yhteiskunnallisen luonteen välillä ratkeaa siten, että tieteen autonomian ydin, tieteellisyys, yhdistetään oikeaan käsitykseen tiedettä eteenpäin vievästä yhteiskunnallisesta dynamiikasta, toisin sanoen käsitykseen tieteen ja yhteiskunnallisen edistyksen liiton välttämättömyydestä. Tämä tarjoaa ratkaisun myös kysymykselle yksityisen tutkijan vastuusta: Jokainen tutkija henkilökohtaisesti on vastuussa työnsä tieteellisestä tasosta sekä omasta liittoutumisestaan edistyk- sellisten voimien kanssa; sen sijaan kukaan ei yksin voi vastata tieteen tulosten yhteiskunnallisesta soveltamisesta, se on koko edistyksellisen liikkeen tehtävä.

Nimenomaan tässä mielessä tieteen autonomia, siis tieteellisen yhteisön autonominen, yhteiskunnallisen edistyksen asemista lähtevä toiminta on uhattuna Suomessa yhtä lailla kuin muuallakin kapitalistisessa maailmassa. Tieteen autonomian puolustaminen on yksi tieteen puolustamisen momentteja.

Vielä yhden mielenkiintoisen rinnastuksen Suomen olosuhteisiin tarjoaa Metzgerin kirjoituksen jakso, jossa hän tarkastelee porvarillisen ideologian kriisin vaikutusta tieteen kehitysedellytyksiin Ranskassa. Metzgerin näkökohdista ensimmäinen on se, että irrationalistisia ja fatalistisia näkemyksiä suositaan aktiivisesti, jotta voitaisiin hämärtää se umpikuja, johon ranskalainen kapitalismi on joutunut, ja jonka kirkkaimpiin osoituksiin kuuluu juuri tutkimuksen ehtojen kuristaminen. Irrationalismia kuitenkin käytetään myös suoranaisiin tieteen vastaisiin hyökkäyksiin, ei pelkästään "neutraalina" sumuverhona. Tyypillistä on esittää, että kapitalismin yhteiskunnalliset ristıriidat ovat tieteen ja yhteiskunnallisen kehityksen väistämättömiä seuralaisia. Esimerkiksi presidentti Pompidou esitti tämän epä-paradoksin vuonna 1971 pitämässään puheessa: "Miten tulee ratkaista tämä ihmiselle ominainen ristiriita? Hän hyväksyy tiedon edistysaskeleet, mutta samanaikaisesti yrittää tehdä vastarintaa edistyksen väistämättömille seurauksille."

Suomestakin toki tunnemme irrationalismiin perustuvat tieteen vastaiset lausunnot. Suomessa tunnemme ne kuitenkin vielä määrätietoisemmin taantumukselliseen yhteiskunnalliseen ideologiaan nojautuvina, vielä määrätietoisemmin sisällöltään poliittisina.

Tunnettuja ovat Seppo Sisätön "Nollatutkimus" -kirjoitelman jälkeiset tieteen vastaiset haukut. Tälle vyörytykselle olivat taantumusvoimat kuitenkin luoneet perustaa jo pidempään. Antti Eskol a kirjassaan Yhteisiä asioita (Vaasa 1972) esittää lainauksen silloisen Tampereen yliopiston professorin, nykyisen kokoomuksen kansanedustajan Erkki Pystysen lehtihaastattelusta: "Professori Pystynen kysyy, mitä sitten olisi tehtävä, jos opetusta todetaan käytettävän yhteiskuntajärjestelmämme kumoamisen välineenä. Hänen mukaansa ensin on selvitettävä, onko tällainen lain mukaan hyväksyttävää ja sallittua. Myös tulisi selvittää, olisiko opetuksen sisältöä koskevat perusnormit määrättävä erityisessä laissa, josta riittävän selvästi kävisi ilmi eri ideologioiden asema opetuksessa."

Pystynen on lausunnollaan ennakoinut tilannetta, jossa "pelkkä" syrjintä, tutkijoiden työmahdollisuuksiin kohdistuva vaino, laajenee teoriakielloksi, pyrkimykseksi lakaista eräs, nimenomaan marxilainen, tutkimusperinne olemattomiin. Tämä tilannehan on nykypäivän todellisuutta Saksan Liittotasavallassa. Eskola esittää kirjassaan mielenkiintoisen, tähän liittyvän ennusteen: "Kenties olen pessimisti, mutta ennustan, että perinteinen opetuksen ja tutkimuksen vapaus alkaa pian olla yliopistoissamme vaarassa, ja että sen rajoittajana on juuri oikeisto, jonka päivästä toiseen näemme taistelevan sananvapautta vastaan myös kouluissa, kustannustoiminnan piirissä, Yleisradiossa jne." Voimme tällä hetkellä todeta, että 


\section{ELÄMÄNTAPATUTKIMUSTA JA SOSIAALIPOLITIIKKAA NEUVOSTOLITOSSA}

Eskolan ennuste on epämiellyttävän kirjaimellisesti toteutunut.

Etsiessään vaihtoehtoa Ranskassa nykyisin vallitsevalle tilanteelle Metzger asettaa keskeiselle sijalle demokratian: "Tiede ja demokratia kuuluvat erottamattomasti yhteen. Tiede tarvitsee demokratiaa, tutkimuksen, kiistelyn ja julkaisutoiminnan vapautta."

Demokratian vaatimus koskee tieteellisen yhteisön sisäisiä periaatteita, joissa demokratian vaatimus ja byrokraattisen määräilyn kieltäminen on yhtä kuin tieteellisyyden vaatimus. Mutta se koskee myös koko yhteiskuntaa. Voisi vieläpä sanoa, että demokratian vaatimus koskee korostetusti yhteiskuntaa.

Yhteiskunnallinen demokratia ja tieteellisyys ovat tieteen puolustamisen tunnukset. Niiden varassa etenee tutkimus sosialistisissa maissa. Niihin nojautuu tutkijoiden edistyksellinen liike kapitalistisissa maissa.

Yrjö Haila
VTT J.P. Roos vieraili vaihtostipendiaatina Neuvostoliitossa syyskuussa 1976. Matkaohjelma käsitti tutustumisen Moskovassa sijaitseviin yhteiskuntatieteellisiin instituutteihin, ennen kaikkea Kansainvälisen työväenliikkeen Instituuttiin (Institut mezhdunarodnogo rabotshego dvizhenia, IMRD) ja Sosiologisen tutkimuksen instituuttiin (Institut sotsiologitsheskih issledovania). Lisäksi hän tapasi alansa tutkijoita Marxismi-leninismin instituutista (Institut marksism-leninizm), Taloudellis-matemaattisesta keskusinstituutista (Tsentralnyi-ekonomiko-matematitsheskii institut) sekä Yhteiskuntatieteiden akatemiasta. Seuraavassa Roos kuvaa näiden laitosten tutkimusta ja selostaa eräitä käymiään keskusteluja.

\section{Yleistä Neuvostoliton}

yhteiskuntatieteiden kehityksestä

Tieteellinen tutkimus Neuvostoliitossa jakautuu toisaalta yliopistoissa suoritettavaan tutkimukseen sekä toisaalta Tiedeakatemian instituuteissa suoritettavaan tutkimukseen. Yliopistot vastaavat alan peruskoulutuksesta kun taas Tiedeakatemian instituutit vastaavat jatkokoulutuksesta. Tiedeakatemian instituuttien tehtävänä on edistää sekä alan perustutkimusta että myös hyvin pitkälle vietyä sovellettua tutkimusta, mikä muodostaakin pääosan tutkimuksesta, $n$. $80 \%$. Erityisesti yhteiskuntatieteissä on paine käytännön sovellutuksiin suuri. Yhteiskuntatieteellisen tutkimuksen kehityksestä Tiedeakatemiassa vastaa Tiedeakatemian presidiumin yhteiskuntatieteiden jaosto sekä sen alaiset tiedeneuvostot (11 kpl v. 1976) sekä Yhteiskuntatieteellisen informaation instituutti (Institut nautshnoi in- formatsii po obshsestvennym naukim INION).

Neuvostoliiton yhteiskuntatieteiden kehitys on ollut ennennäkemättömän nopeaa 1960-luvun lopulta lähtien, jolloin NKPn keskuskomitea hyväksyi päätöslauselman yhteiskuntatieteiden kehittämisestä (1967). Tosin yhteiskuntatieteillä oli aikaisemminkin ollut vankka asema tieteiden järjestelmässä - muodostavathan historiallinen materialismi ja poliittinen taloustiede marxilaisen yhteiskuntatieteen rungon - mutta erityisesti konkreettisen tutkimuksen sekä tieteellisen erikoistumisen kasvu on tapahtunut 1960-luvulta lähtien. (Ks. Gapotschka, Marlen Smirnov, Stanislav: The social sciences in the USSR status, policy, structures and achievements. International Social Science Journal 28 (1 1976)).

Opiskelijamäärien kasvu yleensä yhteiskuntatieteissä on ollut voimakasta joskin eräillä aloilla on tapahtunut suhteellista jälkeenjäämistä: esimerkiksi kasvatustieteissä ja historiassa, jotka olivat vielä 1950 suurimpien alojen joukossa. Nopeimmin kasvanut yhteiskuntatiede on taloustiede, joka on tällä hetkellä yksi "kolmesta suuresta" tiedelohkosta; kaksi suurta ovat tekniikka sekä fysiikka ja matematiikka.

Jos tarkastellaan esimerkiksi Neuvostoliiton sekä eri tasavaltojen tiedeakatemioiden instituuttien sosiologisten osastojen perustamisvuosia päästään seuraavaan jakautumaan (lähde: Sotsiologitsheskie tsentri SSSR 1976):

Perustamisvuosi

Lukumäärä

ennen 1960

1971-75 